\title{
Day Long Effect of Liquidity on Stock Return: An Empirical Investigation in a Day of Political and Economic Importance in India
}

\author{
Trilochan Tripathy ${ }^{1} \&$ Eshan Ahluwalia ${ }^{1}$ \\ ${ }^{1}$ IBS Hyderabad, The IFHE Deemed to-be University, Hyderabad, India \\ Correspondence: Eshan Ahluwalia, IBS Hyderabad, The IFHE Deemed to-be University, Hyderabad, TS, \\ 501203, India. Tel: 91-981-902-1830. E-mail: eshanwalia@ gmail.com
}

Received: July 22, 2015

Accepted: August 17, 2015

Online Published: September 25, 2015

doi:10.5539/ijef.v7n10p204

URL: http://dx.doi.org/10.5539/ijef.v7n10p204

\begin{abstract}
Market events that build up high degree of uncertainty and expectation are an interesting case to study the relationship between liquidity and equity return in any economic system. This study examines the day long effect of liquidity on the equity return in the day during government budget announcement. Using the OLS and ARDL models, the study establishes the direction and magnitude of relationship between different liquidity proxies and intraday stock returns in Indian equity market. The empirical evidence suggests that returns have significant dynamic negative relationship with liquidity measures. Further the effects of liquidity on stock returns are relatively prominent during the period of budget speech than the period of post budget announcement. The study concludes that the absolute spread as a liquidity measure plays an important role in driving a day long equilibrium dynamics of intraday stock returns in Indian market.
\end{abstract}

Keywords: liquidity, dynamic liquidity, return, absolute spread, relative quoted spread, illiquidity, ARDL model

\section{Introduction}

Liquidity is risky and the return sensitive to market liquidity is priced (Pastor \& Stambaugh, 2003). Liquidity co-moves with returns and predicts future returns (Amihud, 2002; Chordia et al., 2001a; Jones, 2001; Bekaert et al., 2003). Liquidity is a critical factor that explains risk and return dynamics in the market (Amihud et.al., 2005; Brennan \& Subrahmanyam,1996; Liu, 2006; Acharya \& Pedersen, 2005). Empirical literature also confirms that return premium is also due to commonality in liquidity (Chordia et al., 2000; Huberman \& Halka, 1999; Hasbrouck \& Seppi, 2001). The literature also evidences that there is a positive relationship between a stock's uncertainty elasticity of liquidity (UEL) and its expected return (Sun \& Yu, 2015). Liquidity proxies used in most of the literature have been applied either on Daily, Weekly or Monthly basis. But, the existing literature provides the fitness of liquidity proxies to explain the expected stock returns in the period of uncertainty. However, market event that build up high degree of uncertainty and expectation is an interesting case to study the relationship between liquidity and equity return in any economic system. Against this backdrop, the present study examines the effect of liquidity on individual stock return in the day of union government budget presentation in India.

We have not come across with any study that attempts to understand the day long effect of liquidity on the equity return in the event of government budget announcement. The budget announcement in the Indian market is a classic event to get an insight into such a relationship. We conjecture that market may be exposed to liquidity shocks during the pre and post union budget announcement in the Indian market. Further the stock's liquidity might have a role in determining its return. Against this backdrop, we have made an attempt to understand the how does liquidity behaves before and after the budget announcement and its impact on equity returns. Using high frequency data, we investigate this question in the India stock market and provide evidence to show the effect of stock's liquidity on its expected return in the day of union government budget announcement. Further we also study the effect of stock's liquidity on its return across the industries in the day of union budget announcement. Thus, the present study has made an attempt to test the three hypotheses i.e. (i) that contemporaneous and lagged liquidity has a negative impact on stock returns on the day of Union Budget announcement, (ii) returns have significant dynamic relationship with liquidity measures (iii) effect of liquidity on stock returns are prominent during budget speech than the post budget announcement.

Every emerging market is different, with country specific liquidity risks, institutional and corporate governance 
issues and insider trading concerns. Literature suggests that liquidity impact is relatively felt more in the emerging markets than the developed markets due to the local liquidity risks (Bekaert et al., 2007). Thus, it becomes a good case to study the liquidity and return relationship in the day of a specific event when other global markets are on holiday. Understanding of the intraday liquidity pattern using different proxies gives us an idea about the variations in the liquidity of equity stocks (see Amihud, Mendelson, \& Pedersen, 2005). Out of the wide arrays of liquidity proxies, we have selected 'absolute spread' (Chordia et al., 2001), 'relative spread (McInish \& Wood, 1992), 'illiquidity measure'(Amihud, 2002), 'effective spread' (Chorodia et al., 2000) and 'volume based liquidity measure (Admati \& Pfleiderer, 1988) as liquidity proxies for the present study. The Indian union budget is a mega annual political and financial event that builds up high degree of expectations and uncertainties among the key stakeholders. The budget announcement may jolt or cheer up the stakeholders expectations. The stock market also roars to the budgetary resource allocation made by the government to the different sectors of the economy during the budget announcement. The importance of this event can be well understood by studying the high or low turnover in the stock market. The budget announcement in 2015, shoot up the National Stock Exchange turnover into INR 89 Billion, which is five times higher than the average day turnover. Further, Indian Budget 2015 was announced on 28th Feb 2015, which happens to be a Saturday, still prominent exchanges like NSE and BSE decided to open the market as normal business day to account for the volatility that might impact due to the budget announcement.

To best of our knowledge, literature is silent in examining the effect of stock's liquidity on its return in the day of political and economic importance at least in India. This study adds to understanding of market microstructure mechanism to choose appropriate information model derived out of high frequency data. This study contributes to Market Microstructure literature in adding a new dimension of liquidity pattern on the budget day. This study would be beneficial to policy makers, financial institutions and investors looking forward to decipher the code of budget. In my understanding there is no high frequency data analysis being done for budget day. Market participants benchmark the budget expectation using the Nifty Index. Popularity of Nifty Index is shown with highest turnover in underlying derivatives. Hence, we use Nifty Index constituents Intraday. The empirical evidence on relationship between liquidity and return and is mixed across the emerging markets. Our study is an extension of (Lesmond, 2004), where he examines liquidity and return relationship engaging 5 liquidity measures for 23 emerging countries. However, our study is different from him in two different counts i.e. we attempts to understand the liquidity and return relationship in the day of a major political and economic event, which has a bearing on the market sentiment and this investigation is made only in a specific emerging economy context.

Using the OLS and ARDL models, the study establishes the direction and magnitude of relationship between different liquidity proxies and intraday stock returns in Indian equity market. The empirical evidence suggests that returns have significant dynamic negative relationship with liquidity measures. Further the effects of liquidity on stock returns are relatively prominent during the period of budget speech than the period of post budget announcement. The study concludes that the absolute spread as a liquidity measure plays an important role in driving a day long equilibrium dynamics of intraday stock returns in Indian market.

The paper is organized as follows. Section 2 describes the data and methodology. Section 3 contains an empirical analysis and Section 4 contains the conclusion.

\section{Data and Methodology}

\subsection{Data Sources}

The study is based on secondary intraday tick by tick data for Nifty 50 stocks. The Nifty 50 stock s are the major constituent stocks of the National Stock Exchange of India Ltd. (NSE). The period of the study spans around the Government of India's Budget Announcement Day of 2015 (Note 1). The data is exclusive in the sense that it is directly obtained from connecting to broker's market data terminal for the budget session and post budget session. The rationale of choosing NSE emanates from the fact that it is one of the top 15 largest stock exchanges in the world and the largest in India by market capitalization, daily turnover and number of trades both for equities and derivative. NSE is mutually owned by a set of leading financial institutions, banks, insurance companies and other financial intermediaries in India but its ownership and management operate as separate entities. There are two foreign investors, NYSE Euronext and Goldman Sachs, with a stake in the NSE. The NSE VSAT1 terminals, 2799 in total, cover more than 1500 cities across India. In 2011, the NSE was the third largest stock exchange in the world in terms of the number of contracts (1221 million) traded in equity derivatives. It is the second fastest growing stock exchange in the world with a recorded growth of $16.6 \%$. NSE Cash trading happens in Capital market (CM) segment. Trading in equities takes place in the CM segment of NSE on all 
weekdays except holidays declared by the exchange in advance. The market timing for the equities segment is from 9:15 am to 3:30 pm. However, due to a special budget day session the market was kept open during the budget day. All orders which are of regular lot size (Rs. 5 Crore) or multiples thereof are traded in the normal market. All orders whose order size is less than the regular lot size are traded in the odd-lot market. In the auction market, auctions are initiated by the Exchange on behalf of trading members for settlement related reasons.

\subsection{Sample Stocks}

NIFTY 50 stocks (Note 2) constitute closely 75 per cent of the entire market capitalization of the market. The data is filtered after removing for non zeros per second giving on an average of 14 records per minute for low volume stocks as Grasim and about 68 records per minute for stocks like Reliance. Further, adopting Center for Monitoring Indian Economy (CMIE) industry sub-classification method, NIFTY 50 stocks are classified under 21 distinct industries. Reaction to budget news is at Industry level and for the purpose of this paper we have classified Cement and Infrastructure stocks are captured as one group. On other hand stocks like Grasim, Reliance, LT belonging to Diversified groups are classified into respective sectors where the weights of their business is high. With this we are able to create approximately 9 industries.

\subsection{Variables Description}

The market broadcasts about 22 parameters for each stock at level quotes. As per variables are concerned, the present study employed a host of liquidity proxies and stock price information based on earlier empirical studies on return and liquidity linkage. We have refined the raw data to construct liquidity proxies and stock return for our empirical analysis as the liquidity as a measure is not directly observable, further the nature of liquidity is multidimensional and it can be captured in a single measure. In constructing liquidity proxies, the attributes like Bid Quantity, Ask Quantity are mere reflections only as traders are allowed to hide $10 \%$ of their volumes. However, these parameters are fundamental component of reflecting in calculation of these proxies as per literature defining liquidity from intraday perspective. Thus, to reflect the diversified liquidity conditions in stocks, 3 liquidity measures are used in the empirical examination. The liquidity measures are Absolute Spread (AS), Relative Spread (RS), Effective Spread (ES), Amihud Liquidity Measure (ILLIQ) and Log Number of Transaction (LNT). Our work follows the liquidity proxy construction methodology of the followings:

a. Absolute Spread: (Chordia Roll \& Subhramanyam, 2001) $\mathrm{S}_{\mathrm{j}, \mathrm{t}}$ use absolute spread as crude measure of liquidity. It is captured in the following formula:

$$
\left|S_{j, t}\right|=\sum^{i} A B S\left(b_{t, j}-a_{t, j}\right)
$$

Where $b_{t, j i}$ is the best bid price in order book while $a_{t, j}$ is best ask price in same tick of order book.

b. Relative Spread: McInish and Wood (1992) use relative spread or percentage bid-ask spread as preferred measure of risk, and is calculated as the bid-ask spread divided by the simple average of the bid-price and the ask-price.

$$
\operatorname{Re} l S=\sum \frac{2(b-a)}{b+a}
$$

Where $b_{t, j i}$ is the best bid price in order book while $a_{t, j}$ is best ask price in same tick of order book.

c. Effective Spread: (Chordia et al., 2000). Proportionality of effective spread captures the fixed transaction cost.

$$
\operatorname{EffS}_{j, t}=\sum\left(l t p_{j, t}-a t p_{j, t}\right)
$$

Where $1 t p_{t, j}$ is the last traded price per stock and atpt,j is average traded price as broadcasted by exchange for day's transactions.

d. Amihud Liquidity Measure (ILLIQ): Very commonly used measure of liquidity is used for intraday liquidity patterns. This measure is not known for the high frequency liquidity analysis. However, we test this proxy against returns.

$$
\operatorname{IILI} Q_{i, t}=\frac{1}{N} \sum_{i=1}^{i, t} \frac{R_{i, t}}{\operatorname{Vol}_{i t}}
$$


Where Ri,t is the return on tick by tick basis for stocks and Vol i,t while the volume is the total volume at that point of time stamp.

e. Trading Volume: Admati and Pfleiderer (1988) theory of explains intraday quantity traded explains variability of Liquidity pattern. In given time interval how many transactions has happened. As number of transactions increases the liquidity in particular stock increases.

$$
W t=\sum t t q_{i, t}-t t q i_{t-1}
$$

Where ttq is total traded quantity and at $\mathrm{t}-1$ the difference of number of transactions is taken. The continuous return series is calculated from the last trade price. The formula used in calculating return series is as follows:

$$
R_{i, t}=\log \left(\operatorname{LTP}_{i, t} / L T P_{i, t-1}\right)
$$

Where Ri,t is the log return calculated from Last traded price per tick.

\subsection{Estimation Issues}

While working with the time series data, all the problems associated with it must be scrutinized carefully in order to avoid the spurious regression. Scrutinizing time series problems encompasses checking the sationarity of the series, serial correlation in disturbance term and endogenity in the presence of lagged dependant variable. Before moving ahead with the empirical estimation in a panel model framework, it is necessary to determine whether the data series under investigation are free from unit roots. We have carried out five panel unit root test i.e. Levin, Lin and Chu t (2002) Breitung t-stat (2000), Im, Pesaran and Shin W-stat (2003), ADF-Fisher Chi-square (2003), PP-Fisher Chi-square test to confirm the stationary in our data series. However, our work more closely follows Im et al. (2003) methodology for testing unit root in the data series. This methodology proposed a test to investigate the existence of unit roots in panels that combines information from time series as well as cross section dimensions.

To deal with the problem of serial correlation in disturbance terms, we have followed the works of Keane and Runkle (1992) and Kim et al. (2003). These studies have proposed the forward-filtering 2SLS method to tackle the issue of serial correlation. The issues of endogenous of the lagged dependent variable in the ARDL framework can be effectively tackled by the Two-Stage Least Squares technique. Finally the issues of serial correlation and endogeneity are tackled by the adoption of Three Stage Least Squares technique, which combines both the Two-Stage Least Squares technique and the Seemingly Unrelated Regression (SUR) technique.

\subsection{Model Specification}

Linear Regression and Auto Regressive Distributive Lag models with different lag lengths are engaged in the empirical examination. The most popular dynamic model for panel data is Auto Regressive Distributive Lag model where a few lagged dependant and current and lagged explanatory variables explains the change in dependant variables. Building dynamic model with auto regressive distributive lag structure on very large number of intraday high frequency observations would help better capturing true dynamics in a pooled model set up. The models engaged in the empirical examination are presented hereunder:

$$
r_{i t}=\alpha+\beta_{1} L_{i t}+\delta D_{a f t e r}+\varepsilon
$$

Where, $r_{i t}$ is the return and $\mathrm{L}_{\mathrm{i}, \mathrm{t}}$ is Liquidity proxy while $\mathrm{D}_{\text {after }}$ is a dummy variable 0 stands for during budget speech and 1 stands for after budget speech.

$$
r_{i, t}=\alpha+\beta_{1} L_{i, t}+\varphi D_{\text {ind }}+\delta D_{\text {affer }}+\varepsilon
$$

Where, $r_{i t}$ is return of stock per tick and $\mathrm{L}_{\text {it }}$ (Liquidity proxy) and $\mathrm{D}_{\text {after }}$ is a dummy variable 0 stands for during

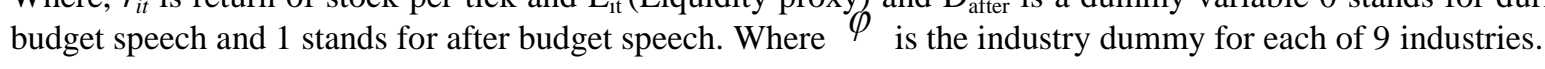

$$
r_{i, t}=\alpha+\beta_{1} L_{i, t}+\beta_{2} L_{i, t-1}+\phi r_{i, t-1}+\delta D_{a f t e r}+\varepsilon
$$

Where, $r_{i t}$ is return of stock per tick and $\mathrm{L}_{\mathrm{it}}$ (Liquidity proxy) and $\mathrm{D}$ is a dummy variable 0 stands for during budget speech and 1 stands for after budget speech. 


$$
r_{i, t}=\alpha+\beta_{1} L_{i, t}+\beta_{2} L_{i, t-1}+\beta_{3} L_{i, t-2}+\phi_{1} r_{i, t-1}+\phi_{2} r_{i, t-2}+\delta D_{a f t e r}+\varepsilon
$$

Where, $r_{i t}$ is return of stock per tick and $\mathrm{L}_{\mathrm{it}}$ (Liquidity proxy) and $\mathrm{D}$ is a dummy variable 0 stands for during budget speech and 1 stands for after budget speech. However based on the AIC and SBC criterion an optimal model is selected for the final empirical examination.

\section{Empirical Findings}

\subsection{Preliminary Findings}

This segment analyzes the results of descriptive statistics and correlation analysis of the constructs and variables those are used in the empirical examination. The mean value of return is seen to have been positive in the day of Union Budget Announcement, which suggests that the Government's action has a positive impact on the overall market return. However the average return obtained from NIFTY after post budget announcement remained sluggish as compared to the during the budget announcement. However the standard deviation of the overall NIFTY return is observed to be relatively higher during the budget speech than the post budget speech period. This result suggests that market is remaining more volatility and uncertain during budget speech than the post budget speech. Further the liquidity proxies also indicated that the market remained relatively less liquid during the budget speech than the post budget speech. It is apparently observed that the return is observed to be inversely associated with spread. As can be seen from Figure-1 the stocks with higher spreads are having negative relationship with returns. Further the coefficient of correlation between return and liquidity measures also provide the inverse relationship between return and liquidity proxies (Table 1). We have examined this relationship using linear regression and ARDL models which are presented in next section.

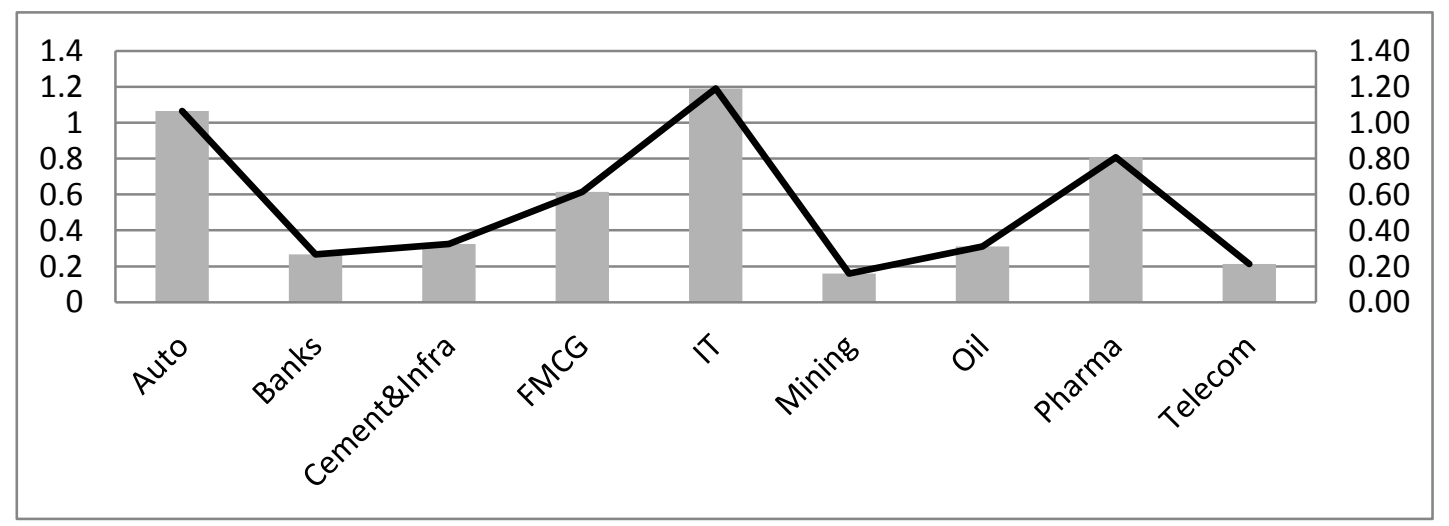

Figure 1. Return and spread association in the day of budget announcement

Note. The left vertical $\mathrm{y}$-axis measures the stock return and the right vertical $\mathrm{y}$-axis measures absolute spread and the $\mathrm{x}$-axis captures the name of industries.

Table 1. Correlation across the variables

\begin{tabular}{cccccc}
\hline & $\mathrm{r}$ & $\mathrm{s}$ & AML & RelS & EffS \\
\hline $\mathrm{r}$ & 1 & & & & \\
$\mathrm{~s}$ & -0.21544 & 1 & 1 & & \\
AML & -0.12184 & -0.0026 & -0.00124 & 1 & \\
RelS & -0.06094 & $0.84967 * *$ & 0.49615 & 0.41238 & 1 \\
EffS & -0.02174 & 0.11343 & & & \\
\hline
\end{tabular}

While examining the stationary properties of the data series, we have carried out industry wise unit root test and the result is presented in Table 2. It is observed that all the series under investigation at industry level are stationary. Further the panel unit root test results irrespective of the methods of investigation suggest that there are no panel unit roots in series pairs under investigation (Table 3 ). 
Table 2. Unit root tests (ADF) across industry segments (null hypothesis: series has unit root)

\begin{tabular}{|c|c|c|c|c|c|c|}
\hline INDUSTRY & return & spread & Relative Spread & Effective Spread & ILLIQ & LNT \\
\hline \multicolumn{7}{|c|}{ INTERCEPT } \\
\hline \multirow[t]{2}{*}{ Auto } & $-1.07 * * *$ & $-0.33 * * *$ & $-0.25^{* * *}$ & $-0.395 * * *$ & $-0.23 * * *$ & $-0.392 * * *$ \\
\hline & $(-24.05)$ & $(-11.34)$ & $(-9.59)$ & -11.177 & 10.06 & (12.69) \\
\hline \multirow[t]{2}{*}{ Bank } & $-0.99 * * *$ & $-0.99 * * *$ & $-0 . .9915 * * *$ & $-0.995^{* * *}$ & $-0.23 * * *$ & $-0.109^{* * *}$ \\
\hline & $(-32.56)$ & $(-108.89)$ & $(-108.85)$ & $-(108.8)$ & -10.06 & $-(14.69)$ \\
\hline \multirow[t]{2}{*}{ Cement \& Infra } & $-0.849 * * *$ & $-0.425^{* * *}$ & $-0.249 * * *$ & $-0.49 * * *$ & $-0.20 * * *$ & $-0.25 * * *$ \\
\hline & $(-39.57)$ & $(-16.27)$ & $(-13.57)$ & -18.74 & -8.852 & -11.09 \\
\hline \multirow[t]{2}{*}{ FMCG } & $-0.8413 * * *$ & $-0.128 * * *$ & $-0.13^{* * *}$ & $-0.234 * * *$ & $-0.19 * * *$ & $-3.17 * * *$ \\
\hline & $(-25.31)$ & $(-13.27)$ & $(-0.132)$ & $(-23.09)$ & $(-8.99)$ & $(-51.06)$ \\
\hline \multirow[t]{2}{*}{ IT } & $-1.01 * * *$ & $-0.128 * * *$ & $-0.50 * * *$ & $-0.55 * * *$ & $-0.36 * * *$ & $-4.94 * * *$ \\
\hline & $(-83.24)$ & $(-13.27)$ & $(-25.99)$ & $(-21.90)$ & $(-24.66)$ & $(-19.69)$ \\
\hline \multirow[t]{2}{*}{ Mining } & $-1.00 * * *$ & $-0.37 * * *$ & $-0.49 * * *$ & $-0.48^{* * * *}$ & $-0.44 * * *$ & $-0.49 * * *$ \\
\hline & $(-94.32)$ & $(-19.81)$ & $(-22.67)$ & $(-21.90)$ & $(-15.07)$ & $(-15.51)$ \\
\hline \multirow[t]{2}{*}{ Oil } & $-1.02 * * *$ & -0.43 & $-0.45^{* * *}$ & $-0.486^{* * *}$ & $-0.34 * * *$ & $-0.470 * * *$ \\
\hline & $(-98.98)$ & $(-21.51)$ & $(-23.12)$ & $(-20.589)$ & $(-13.39)$ & $(-13.002)$ \\
\hline \multirow[t]{2}{*}{ Pharma } & $-0.979 * * *$ & $-0.483^{* * *}$ & $-0.55^{* * *}$ & $-0.75^{* * *}$ & $-0.41 * * *$ & $-0.425 * * *$ \\
\hline & $(-76.11)$ & $(-15.39)$ & $(-23.16)$ & $(-28.80)$ & $(-15.22)$ & $(-16.89)$ \\
\hline \multirow[t]{2}{*}{ Tele } & $-1.19 * * *$ & $-0.403^{* * *}$ & $-0.403^{* * *}$ & $-0.59 * * *$ & $-0.58 * * *$ & $-0.805^{* * *}$ \\
\hline & $(-61.23$ & $(-19.19)$ & $(-19.19)$ & $(-25.98)$ & $(-19.21)$ & $(-21.66)$ \\
\hline \multicolumn{7}{|c|}{ Intercept and Trend } \\
\hline \multirow[t]{2}{*}{ Auto } & $-1.07 * * *$ & $-0.388 * * *$ & -0.251 & $-0.395^{* * *}$ & $-0.50 * * *$ & $-0.47 * * *$ \\
\hline & $(-24.05)$ & $(-12.31)$ & $(-9.69)$ & $(-11.177)$ & -14.11 & (13.88) \\
\hline \multirow[t]{2}{*}{ Bank } & $-0.99 * * *$ & $-0.9915^{* * *}$ & $-0.999 * * *$ & $-0.995^{* * *}$ & $--0.80 * * *$ & $-1.185^{* * *}$ \\
\hline & $(-32.56)$ & $(-108.85)$ & -108.8487 & $-(108.8)$ & $(-32.051)$ & $(-15.297)$ \\
\hline \multirow[t]{2}{*}{ Cement \& Infra } & $-0.845^{* * *}$ & $-0.648 * * *$ & $0.27 * * *$ & $-0.55 * * *$ & $-0.20 * * *$ & $-0.292 * * *$ \\
\hline & $(-39.57)$ & $(-28.51)$ & $(-14.47)$ & $(-19.74)$ & $(-8.852)$ & $(-12.00)$ \\
\hline \multirow[t]{2}{*}{ FMCG } & $-0.8413 * * *$ & $-0.128 * * *$ & $0.1324 * * *$ & $-0.239 * * *$ & $-0.65^{* * *}$ & $-3.29 * * *$ \\
\hline & $(-25.37)$ & $(-13.27)$ & $(-13.58)$ & $(-23.014)$ & $(-26.72)$ & $(-52.26)$ \\
\hline \multirow[t]{2}{*}{ IT } & $-1.00 * * *$ & $-0.51 * * *$ & $-0.4915^{* * *}$ & $-0.57 * * *$ & $-0.81 * * *$ & $-0.52 * * *$ \\
\hline & $(-84.09)$ & $(-26.86)$ & $(-26.04)$ & $(-22.80)$ & $(-41.66)$ & $(-20.96)$ \\
\hline \multirow[t]{2}{*}{ Mining } & $-1.09 * * *$ & $-0.51 * * *$ & $-0.509 * * *$ & $-0.48 * * *$ & $-0.74 * * *$ & $-0.52 * * *$ \\
\hline & $(-94.19)$ & $(-19.86)$ & $(-23.02)$ & $(-21.16)$ & $(-27.93)$ & $(-15.95)$ \\
\hline \multirow[t]{2}{*}{ Oil } & $-1.02 * * *$ & $-0.44 * * *$ & $-0.430 * * *$ & $-0.49 * * *$ & $-0.80 * * *$ & $-0.49 * * *$ \\
\hline & $(-98.98)$ & $(-21.77)$ & $(-23.85)$ & $(-20.06)$ & $(-42.13)$ & $(-13.39)$ \\
\hline \multirow[t]{2}{*}{ Pharma } & $-0.979 * * *$ & $-0.600^{* * *}$ & $-0.56^{* * *}$ & $-0.77 * * *$ & $-0.85 * * *$ & $-0.45^{* * *}$ \\
\hline & $(-76.12)$ & $(-20.66)$ & $(-23.34)$ & $(-29.14)$ & $(-48.92)$ & $(-17.45)$ \\
\hline \multirow[t]{2}{*}{ Tele } & $-1.19 * * *$ & $-0.42 * * *$ & $-0.402 * * *$ & $-0.59 * * *$ & $-0.66 * * *$ & $-0.83 * * *$ \\
\hline & $(-61.23)$ & $(-19.19)$ & $(-22.14)$ & $(-25.55)$ & $(-23.40)$ & $(-22.11)$ \\
\hline
\end{tabular}

Note. $* * * * *$ and $*$ indicates ADF value is $\%$ and $10 \%$ level of significance respectively. Figures in parentheses indicate ' $t$ ' values.

Table 3. Panel unit root tests for the variables under investigation (null hypothesis: panel series has unit root)

\begin{tabular}{|c|c|c|c|c|c|c|}
\hline \multirow{2}{*}{ Group } & \multirow{2}{*}{ Test Description } & \multicolumn{2}{|c|}{$\begin{array}{l}\text { Null: Unit root (assumes } \\
\text { common unit root process) }\end{array}$} & \multicolumn{3}{|c|}{$\begin{array}{c}\text { Null: Unit root (assumes individual unit root } \\
\text { process }\end{array}$} \\
\hline & & $\begin{array}{l}\text { Levin, Lin \& } \\
\text { Chu t* }\end{array}$ & $\begin{array}{c}\text { Breitung } \\
\text { t-stat }\end{array}$ & $\begin{array}{l}\text { Im,Pesaran } \\
\text { Shin W-stat }\end{array}$ & $\begin{array}{l}\text { AD - Fisher } \\
\text { Chi-square }\end{array}$ & $\begin{array}{l}\text { PP - Fisher } \\
\text { Chi-square }\end{array}$ \\
\hline \multirow[t]{2}{*}{ Return } & Individual intercept & $-100.36 * * *$ & & $-136.38 * * *$ & $36.84 * * *$ & $36.84 * * *$ \\
\hline & Individual Intercept with trend & $-141.96 * * *$ & $-22.73 * * *$ & $-149.61 * * *$ & $36.84 * * *$ & $18.42 * * *$ \\
\hline \multirow[t]{2}{*}{ Spread } & Individual intercept & $232.34 * * *$ & & $-156.38 * * *$ & $76.43 * * *$ & $49.46 * * *$ \\
\hline & Individual Intercept with trend & $-293.42 * * *$ & $-273.51 * * *$ & $-486.53 * * *$ & $86.41 * * *$ & $39.32 * * *$ \\
\hline \multirow[t]{2}{*}{ Relative Spread } & Individual intercept & $-207.76 * * *$ & & $-436.53 * * *$ & $42.31 * * *$ & $19.72 * * *$ \\
\hline & Individual Intercept with trend & $-293.81 * * *$ & $-140.37 * * *$ & $-482.97 * * *$ & $36.84 * * *$ & $18.42 * * *$ \\
\hline \multirow[t]{2}{*}{ Effective Spread } & Individual intercept & $232.34 * * *$ & & $-146.38 * * *$ & $56.43 * * *$ & $39.46 * * *$ \\
\hline & Individual Intercept with trend & $-293.42 * * *$ & $-213.51 * * *$ & $-446.53 * * *$ & $37.41 * * *$ & $19.32 * * *$ \\
\hline \multirow{2}{*}{$\begin{array}{l}\text { Amihud liquidity } \\
\text { measure }\end{array}$} & Individual intercept & $-207.45^{* * * *}$ & & $-199.55^{* * * *}$ & $27.14 * * *$ & $18.42 * * *$ \\
\hline & Individual Intercept with trend & $-293.42 * * *$ & $-47.84 * * *$ & $-219.50 * * *$ & $36.84 * * *$ & $18.42 * * *$ \\
\hline
\end{tabular}

Note. $* * *, * *$ and $*$ indicates ADF value is $1 \%, 5 \%$ and $10 \%$ level of significance respectively. 


\subsection{Main Findings}

As preliminary step, I run a pool linear regression (Model 1), which can provide the role of liquidity proxy and the budget announcement effect on in stock return on the union budget announcement day. The results of the model 1 estimation are captured in the Table 4. Irrespective of the liquidity proxy used in the model 1, the results suggest that liquidity has significant inverse effect on high frequency intraday stock returns on the day of Union Budget announcement day of 2015. The result also partially support that post budget period announcement intraday stock returns have dampened compared to the period of budget announcement. The results are consistent with our hypothesis that fails to reject for all Liquidity proxies have strong explanatory power for returns, which also supports the theoretical direction between return and liquidity proxies used under empirical examination. We have extended this model adding 9 industry dummies (Model 2) to understand the industries that are significantly influenced by the budget announcement. The result in the presence of spread based liquidity measures suggests that the industries like auto, cement, pharmaceutical, media and information technology intraday return outcome are seen to have been significantly positive compared to rest of the industry segments (Table 5). However, as $\mathrm{R}^{2}$ has lower values, we include the lags in our model to find an optimal fit. Keeping this in mind, I extend the model with the ARDL approaches.

Table 4. Estimates from the combined regression model

\begin{tabular}{ccccc}
\hline Coefficients & Spread & ILLIQ & RelS & EffS \\
\hline$\alpha$ & $0.0001^{* * *}$ & $0.00005^{* * *}$ & $6.9163 \mathrm{E}-06$ & $3.77 \mathrm{E}-06$ \\
& $(7.23)$ & $(3.51)$ & $(0.47)$ & $(0.26)$ \\
$\beta 1$ & $-0.000256^{* * *}$ & $-8411435^{* * *}$ & $-0.0169^{* * *}$ & $-0.000035^{* * *}$ \\
& $(-99.99)$ & $(-55.65)$ & $(-27.67)$ & $(-9.86)$ \\
& $-0.0000162^{* * *}$ & $-431435^{* * *}$ & $-0.000239^{* * *}$ & $-0.0000249 * * *$ \\
& $(-99.99)$ & $(-15.425)$ & $(-17.67)$ & $(-11.456)$ \\
& 0.0000117 & $-0.000025^{* * *}$ & $8.08 \mathrm{E}-06$ & $4.62 \mathrm{E}-06$ \\
$\mathrm{R}^{2}$ & $(0.62)$ & $(-1.30)$ & $(0.42)$ & $(0.24)$ \\
AIC & 0.0464 & 0.0149 & 0.0005 & 0.0037 \\
SBC & -1664169.5 & -1657481.3 & -1655172 & -1654504.7 \\
\hline
\end{tabular}

This table shows the regression result of combined regression model for five liquidity proxy against returns. The Dummy shows the co-efficient of returns after the budget speech is over. The Dummy variable where 0 indicates during the budget speech and 1 post budget speech.

Note. $* * *, * *$ and $*$ indicates $1 \% \mathrm{~m} \mathrm{5 \%}$ and $10 \%$ level of significance respectively Figures in parentheses are $\mathrm{t}$ values.

Table 5. Industry effect on stock return

\begin{tabular}{cc}
\hline$r_{i, t}=\alpha+\beta_{1} L_{i, t}+\varphi\left(D_{\text {ind }}\right)$ & $+\delta D_{\text {after }}+\varepsilon$ \\
\hline Liquidity Proxy & Spread \\
$\alpha$ & $0.00011^{* * * *}$ \\
$\beta_{1}$ & $(2.93)$ \\
& $-0.00026^{* * *}$ \\
$\delta$ & $(-100.31)$ \\
& 0.0000127 \\
Dcem & $(0.67)$ \\
& $0.0000588^{* * *}$ \\
Dbank & $(2.73)$ \\
& 0.0000348 \\
Dauto & $(-1.19)$ \\
& $0.0000424^{* * *}$ \\
Dtel & $(4.49)$ \\
& 0.0000838 \\
Dinfra & $(-0.28)$ \\
& 0.0000274 \\
\end{tabular}




\begin{tabular}{cc}
\hline Doil & 0.0000345 \\
& $(-0.46)$ \\
Dpharma & $0.0000539^{* * *}$ \\
& $(2.41)$ \\
Dit & $0.0000419 * * *$ \\
& $(4.79)$ \\
Dfmcg & 0.0000318 \\
& $(0.36)$ \\
\hline $\mathrm{R}^{2}$ & 0.4462 \\
SBC & -1775593.70000 \\
AIC & -1775757.50000 \\
\hline
\end{tabular}

Note. $* * *, * *$ and $*$ indicates $1 \% \mathrm{~m} \mathrm{5 \%}$ and $10 \%$ level of significance respectively Figures in parentheses are $\mathrm{t}$ values.

We have estimated the first order ARDL $(1,1,1)$ which is specified under Model 3 and the results are captured in Table 6. This model only captures a day long effect of liquidity and auto regressive terms on the intraday stock return. The results presented in this section are estimated using panel pooled mean group with Two Stage Least Square so as to tackle the issues of serial correlation and endogenous in lag dependant variables in the model. As shown by Pesaran and Shin (1999), the ARDL model has additional advantage of producing consistent long run coefficients whether the series are integrated with order 1 or order 0 . As we did not get an issue of non stationary in the series under investigation, we thus have skipped to estimate the short period dynamics in an Error Correction framework. The results of panel pooled mean group estimation for all the stocks under 10 industries are given in Table 6.

The results suggest that the irrespective of intraday contemporaneous and lagged liquidity proxies are likely to have a bigger day long lasting effect on intraday stock returns. In particular, a simple calculation suggests that an adverse $10 \%$ shocks to effective spread is likely to pull back day long equilibrium stock return by $13 \%$. Also the intraday lagged stock returns have also a statistically significant impact on its level value across the ARDL models. However the inclusion of lagged liquidity proxy and auto regressive terms has substantially improved the explanatory power of the model than the base linear regression model. The high $\mathrm{R}$ square value and least values of information criteria across the models suggest better fit and the model with the absolute spread is observed to be the best fit among the models. I estimated a wide array of estimated model based on the model fit criteria ARDL $(2,1,2)$ os observed to be the best fit as the R square values don't improve appreciably beyond ARDL $(2,1,2)$ and the AIC and SBC values obtained to be the least in the this 2nd order ARDL model (Table 7). Thus, it is observed that intraday liquidity condition in the intraday equity market as reflected by absolute spread measure play an important role in driving a day long equilibrium dynamics in intraday stock returns in Indian market.

Table 6. ARDL $(2,1,1)$ model estimates

\begin{tabular}{|c|c|c|c|c|}
\hline \multicolumn{5}{|c|}{$r_{i, t}=\alpha+\beta_{1} L_{i, t}+\beta_{2} L_{i, t-1}+\phi r_{i, t-1}+\delta D_{a f t e r}+\varepsilon$} \\
\hline Coefficients & Spread & ILLIQ & RelS & EffS \\
\hline$\alpha$ & $\begin{array}{c}0.00003 * * \\
(2.15)\end{array}$ & $\begin{array}{c}0.00005 * * * \\
\quad(4.07)\end{array}$ & $\begin{array}{c}0.00000 \\
(-0.19)\end{array}$ & $\begin{array}{c}0.00000 \\
(-0.17)\end{array}$ \\
\hline$\beta_{1}$ & $\begin{array}{c}-0.000468^{* * *} \\
(-188.30)\end{array}$ & $\begin{array}{c}0.06763 * * * \\
(45.80)\end{array}$ & $\begin{array}{c}-0.11560 * * * \\
(-102.8)\end{array}$ & $\begin{array}{c}-0.00004^{* * *} \\
(-13.09)\end{array}$ \\
\hline$\beta_{2}$ & $\begin{array}{c}-0.0000638 * * * \\
(-128.20)\end{array}$ & $\begin{array}{c}0.0144 * * * \\
(-15.60)\end{array}$ & $\begin{array}{c}-0.05245 * * * \\
(-39.8)\end{array}$ & $\begin{array}{c}-0.000015^{* * *} \\
(-3.09)\end{array}$ \\
\hline$\Phi$ & $\begin{array}{c}-0.42680^{* * * *} \\
(-235.62)\end{array}$ & $\begin{array}{c}-0.54940 * * * \\
(-277.93)\end{array}$ & $\begin{array}{c}-0.47450 * * * \\
(-252.36)\end{array}$ & $\begin{array}{c}-0.49850 * * * \\
(-260.75)\end{array}$ \\
\hline$\delta$ & $\begin{array}{c}0.00001 \\
(0.52)\end{array}$ & $\begin{array}{c}-0.00002 \\
(-1.42)\end{array}$ & $\begin{array}{c}0 \\
(0.44)\end{array}$ & $\begin{array}{c}0.00001 \\
(0.39)\end{array}$ \\
\hline $\mathrm{R}^{2}$ & 0.36990 & 0.28810 & 0.28650 & 0.24960 \\
\hline AIC & -1749271 & -1724183 & -1723741 & -1713384 \\
\hline SBC & -1749220 & -1724132 & -1723690 & -1713333 \\
\hline
\end{tabular}

This table shows the regression results along with one level lag for each of liquidity proxy and return lags. Note. $* * *, * *$ and $*$ indicates $1 \% \mathrm{~m} 5 \%$ and $10 \%$ level of significance respectively Figures in parentheses are $\mathrm{t}$ values. 
Table 7. ARDL $(2,1,2)$ model estimates

\begin{tabular}{|c|c|c|c|c|c|}
\hline \multicolumn{6}{|c|}{$r_{i, t}=\alpha+\beta_{1} L_{i, t}+\beta_{2} L_{i, t-1}+\beta_{3} L_{i, t-2}+\phi_{1} r_{i, t-1}+\phi_{2} r_{i, t-2}+\delta D_{a f t e r}+\varepsilon$} \\
\hline Coefficients & Spread & ILLIQ & RelS & EffS & $\log ($ trade $)$ \\
\hline \multirow{3}{*}{$\alpha$} & 0.00001 & $0.00004 * * *$ & 0.00000 & -0.00001 & -0.00001 \\
\hline & $(1.01)$ & (3.31) & $(-0.32)$ & $(-0.43)$ & $(0.0000)$ \\
\hline & $-0.00048 * * *$ & $0.00104 * * *$ & $-0.63980 * * *$ & $-0.00004 * * *$ & 0.000001 \\
\hline \multirow[t]{2}{*}{$\beta_{\mathrm{t}}$} & $(-199.7)$ & $(-50.66)$ & $(-304.54)$ & $(-14.17)$ & $(0.6687)$ \\
\hline & $-0.31339 * * *$ & $-0.048355 * * *$ & $-0.47892 * * *$ & $0.00003^{* * *} *$ & 0.000025 \\
\hline \multirow[t]{2}{*}{$\beta_{2}$} & $(-155.63)$ & $(-65.82)$ & $(-212.45)$ & (3.92) & $(0.204)$ \\
\hline & $-0.62630 * * *$ & $-0.09567 * * *$ & $-0.31760^{* * * *}$ & $0.00002 * * *$ & 0.000004 \\
\hline \multirow[t]{2}{*}{$\beta_{3}$} & $(-301.93)$ & $(-60.78)$ & $(-155.75)$ & (5.89) & $(0.104)$ \\
\hline & $0.00025 * * *$ & $-0.71440^{* * *}$ & $0.09030^{* * * *}$ & $-0.66450^{* * *}$ & $-0.56780 * * *$ \\
\hline \multirow[t]{2}{*}{$\Phi_{1}$} & (93.47) & $(-329.04)$ & $(64.25)$ & $(-319.29)$ & $(-284.11)$ \\
\hline & $0.00019^{* * *}$ & $-0.33230 * * *$ & $0.01010 * * *$ & $-0.33190 * * *$ & $-0.14290 * * *$ \\
\hline \multirow[t]{2}{*}{$\Phi_{2}$} & (72.33) & $(-151.15)$ & $(9.21)$ & $(-159.56)$ & $(-100.75)$ \\
\hline & 0.00001 & -0.00002 & 0 & 0.00001 & 0.00001 \\
\hline$\delta$ & $(0.62)$ & $(-1.02)$ & (0.6) & $(0.54)$ & $(0.0000)$ \\
\hline $\mathrm{R}^{2}$ & 0.44620 & 0.36000 & 0.3622 & 0.33250 & 0.28230 \\
\hline AIC & -1775772 & -1746051 & -1746771.5 & -1737418 & -1943924 \\
\hline SBC & -1775701 & -1745979 & -1746700 & -1737347 & -1943853 \\
\hline
\end{tabular}

Note. $* * *, * *$ and $*$ indicates $1 \% \mathrm{~m} \%$ and $10 \%$ level of significance respectively Figures in parentheses are $\mathrm{t}$ values.

\section{Conclusion}

The study intends to test three hypotheses i.e. (i) that contemporaneous and lagged liquidity has a negative impact on stock returns on the day of Union Budget announcement, (ii) returns have significant dynamic relationship with liquidity measures (iii) effect of liquidity on stock returns are prominent during budget speech than the post budget announcement. Using the OLS and ARDL models, the study establishes the direction and magnitude of relationship between different liquidity proxies and intraday stock returns in Indian equity market during the day of union budget announcement. The study affirms that contemporaneous and lagged liquidity proxies are likely to have a bigger day long lasting effect on intraday stock returns, in line with our first hypothesis. Also the intraday lagged stock returns also have significant impact on its level value across the all the ARDL models, these findings are in line with our second hypothesis of significant dynamic relationship of returns with liquidity measures. However the inclusion of lagged liquidity proxy and auto regressive terms has substantially improved the explanatory power of the model than the base linear regression model. The high $\mathrm{R}$ square value and least values of information criteria across the models suggest better fit and the model with the absolute spread is observed to be the best fit among the models. It is also observed that absolute spread as a liquidity measure drive a day long equilibrium dynamics in intraday stock returns in Indian market. This is exhibited as in equation-4.

However, industry wise analysis suggests that Cement, Auto, Pharmaceutical and IT sectors have highest expectation built up, thus to conclude, the empirical evidences here suggest that returns have significant dynamic negative relationship with liquidity measures. Further the effects of liquidity on stock returns are relatively prominent during the period of budget speech than the period of post budget announcement, which makes economic sense and is in line with our third hypothesis. Apart from absolute spread, the study is in line with other liquidity proxies as a good measure. Effective Spread (Chordia et al., 2000), Relative Spread: McInish and Wood (1992) and Trading Volume: Admati and Pfleiderer (1988) has supported with model. The study concludes that the absolute spread as a liquidity measure plays an important role in driving a day long equilibrium dynamics of intraday stock returns in Indian market. We also claim that this study adds to understanding of market microstructure mechanism to choose appropriate information model derived out of high frequency data and adds a new dimension of liquidity pattern on the budget day. This study would be beneficial to policy makers, financial institutions and investors looking forward to decipher the code of budget. This study may give direction to the future researches to examine the impact of other economic and political events in examining the liquidity return relationships in India or abroad.

However the study is not free from limitations. The sample set included the budget speech and post budget trading. This can be extended to a prior and post trading day out comes. I have chosen to apply variety of proxies 
on focused data set from Budget announcement. However, prior and next day data could be useful to analyze impact of market once the information efficiency The Sample selected was NIFTY 50, however impact on mid cap need to be extended.

\section{References}

Acharya, V. V., \& Pedersen, L. H. (2005). Asset pricing with liquidity risk. J. Financ. Econ. 77, 375-410. http://dx.doi.org/10.1016/j.jfineco.2004.06.007

Admati, A. R., \& Paul, P. (1988). A theory of intraday patterns: Volume and price variability. Review Of Financial Studies, 1, 13-40. http://dx.doi.org/10.1093/rfs/1.1.3

Amihud, Y. (2002). Illiquidity and stock returns: Cross-section and time-series effects. Journal of Financial Markets, 5, 31-56. http://dx.doi.org/10.1017/CBO9780511844393.010

Amihud, Y., \& Mendelson, H. (1989). The effects of beta, bid-ask spread, residual risk, and size on stock returns. Journal of Finance, 479-486. http://dx.doi.org/10.1017/CBO9780511844393.003

Amihud, Y., Hameed, A., Wenjin, K., \& Huiping, Z. (2013) The illiquidity premium: International evidence. Working paper. http://dx.doi.org/10.1016/j.jfineco.2015.04.005

Bekaert, G., Harvey, C. R., \& Lundblad, C. (2003). Liquidity and expected returns: Lessons from emerging markets. Review of Financial Studies, 20, 1783-1831. http://dx.doi.org/10.1093/rfs/hhm030

Breitung, J. (2000). The local power of some unit root tests for panel data. In B. H. Baltagi (Ed.), Nonstationary Panels, Panel Cointegration and Dynamic Panels (pp. 161-177). Elsevier, Amsterdam. http://dx.doi.org/10.1016/S0731-9053(00)15006-6

Chan, K., Hameed, A., \& Wenjin, K. (2013). Stock price synchronicity and liquidity. J. Financ. Mark. 16, 414-438. http://dx.doi.org/10.1016/j.finmar.2012.09.007

Chordia, T., Roll, R., \& Subrahmanyam, A. (2000). Commonality in liquidity. Journal of Financial Economics, 56, 3-28. http://dx.doi.org/10.1016/S0304-405X(99)00057-4

Chordia, T., Roll, R., \& Subrahmanyam, A. (2001). Market liquidity and trading activity. Journal of Finance, 56, 501-530. http://dx.doi.org/10.1111/0022-1082.00335

Cooper, S. K., Groth, J., \& Avera, W. (1985). Liquidity, exchange listing, and stock return performance. J. Econ. Bus., 37, 19-33. http://dx.doi.org/10.1016/0148-6195(85)90003-7

Copeland, T. E., \& Galai, D. (1983). Information effects on the bid-ask spread. The Journal of Finance, 38(5), 1457-1469. http://dx.doi.org/10.1111/j.1540-6261.1983.tb03834

Glosten, L., \& Milgrom, P. (1985). Bid, ask and transaction prices in a specialist market with heterogeneously informed traders. J. Financ. Econ., 14, 71-100. http://dx.doi.org/10.1016/0304-405X(85)90044-3

Goyenko, R. Y., Holden, C., \& Trzcinka, C. (2009). Do liquidity measures measure liquidity? J. Financ. Econ., 92, 153-181. http://dx.doi.org/10.1016/j.jfineco.2008.06.002

Hameed, A., Wenjin, K., \& Viswanathan, S. (2010). Stock market declines and liquidity. J. Financ., 65, 257-293, 1113-1141. http://dx.doi.org/10.1111/j.1540-6261.2009.01529.x

Hasbrouck, J., \& Seppi, D. J. (2001). Common factors in prices, order flows and liquidity. Journal of Financial Economics, 59, 383-411. http://dx.doi.org/10.1016/S0304-405X(00)00091-X

Huberman, G., \& Halka, D. (1999) Systematic Liquidity. Columbia Business School http://dx.doi.org/10.1111/j.1475-6803.2001.tb00763.x

Im, K. S., Pesaran, H., \& Shin, Y. (2003). Testing for unit roots in heterogeneous panels. Journal of Econometrics, 115, 53-74. http://dx.doi.org/10.1016/S0304-4076(03)00092-7

Jones, C. M. (2001). A century of stock market liquidity and trading costs. Graduate School of Business, Columbia University. http://dx.doi.org/10.2139/ssrn.313681

Keane, M. P., \& Runkle, D. E. (1992). On the estimation of panel-data models with serial correlation when instruments are not strictly exogenous. Journal of Business \& Economic Statistics, 10(1), 1-9. http://dx.doi.org/10.1080/07350015.1992.10509877

Kim, S. J., Moshirian, F., \& Wu, E. (2005). Dynamic stock market integration driven by the European Monetary Union: An empirical analysis. Journal of Banking \& Finance, 29(10), 2475-2502. http://dx.doi.org/10.1016/j.jbankfin.2004.09.002 
Levin, A., Lin, C. F., \& Chu, C. S. J. (2002). Unit root tests in panel data: Asymptotic and finite-sample properties. Journal of econometrics, 108(1), 1-24. http://dx.doi.org/10.1016/S0304-4076(01)00098-7

Liu, W. (2006). A liquidity-augmented capital asset pricing model. Journal of financial Economics, 82(3), 631-671. http://dx.doi.org/10.1016/j.jfineco.2005.10.001

McInish, T. H., \& Robert, A. W. (1992). An analysis of intraday patterns in bid/ask spreads for NYSE stocks. The Journal of Finance, 47(2), 753-764. http://dx.doi.org/10.1111/j.1540-6261.1992.tb04408.x

Pastor, L., \& Stambaugh, R. F. (2003). Liquidity risk and expected stock returns. Journal of Political Economy, 111, 642-685. http://dx.doi.org/10.2139/ssrn.279804

Sun, P. W., \& Yu, B. (2015). Uncertainty elasticity of liquidity and expected stock returns in China. http://dx.doi.org/10.2139/ssrn.2547900

\section{Notes}

Note 1. Union Minister of Finance Mr. Arun Jaitly tabled the Annual Budget 2015 in the Indian Parliament on 28th Feb 2015. The Budget Announcement started at 11.00 a.m. and continued for 90 minutes.

Note 2. Industry wise classifications are used based on 9 industries maintaining parsimonious effect.

\section{Copyrights}

Copyright for this article is retained by the author(s), with first publication rights granted to the journal.

This is an open-access article distributed under the terms and conditions of the Creative Commons Attribution license (http://creativecommons.org/licenses/by/3.0/). 